\title{
Scientific Progress in Strategic Management The Case of the Resource-based View
}

\author{
Foss, Nicolai Juul
}

Document Version

Final published version

Publication date:

2005

\section{License \\ CC BY-NC-ND}

Citation for published version (APA):

Foss, N. J. (2005). Scientific Progress in Strategic Management: The Case of the Resource-based View. Center for Strategic Management and Globalization. SMG Working Paper No. 11/2005

Link to publication in CBS Research Portal

\section{General rights}

Copyright and moral rights for the publications made accessible in the public portal are retained by the authors and/or other copyright owners and it is a condition of accessing publications that users recognise and abide by the legal requirements associated with these rights.

Take down policy

If you believe that this document breaches copyright please contact us (research.lib@cbs.dk) providing details, and we will remove access to the work immediately and investigate your claim. 


\title{
Scientific Progress in Strategic Management: The case of the Resource-based view
}

\author{
Nicolai J. Foss \\ SMG WP 11/2005
}

November 2005 
SMG Working Paper No. 11/2005

November 2005

ISBN: 87-91815-13-4

Center for Strategic Management and Globalization Copenhagen Business School

Porcelænshaven 24

2000 Frederiksberg

Denmark

www.cbs.dk/smg 


\title{
Scientific Progress in Strategic Management: The Case of the Resource-based View
}

\author{
Nicolai J. Foss \\ Center for Strategic Management and Globalization \\ Copenhagen Business School \\ Porcelænshaven 24, $2^{\text {nd }}$ fl.; 2000 Frederiksberg; Denmark \\ njf.smg@cbs.dk \\ and \\ Department of Strategy and Management \\ Norwegian School of Economics and Business Administration \\ Breiviksveien 40; N-5045; Bergen; Norway
}

\section{November 2005}

Prepared for a special issue of The Journal of Learning and Intellectual Capital on

"Twenty Years after the Resource-based View,"

edited by Patricia Ordonez de Pablos, Margaret Peteraf, and Juan Ventura.

Acknowledgments: I am grateful to Patricia Ordonez de Pablos for her encouragement and to Teppo Felin and JW Stoelhorst for fine comments and discussions that have influenced the arguments in this paper. 


\title{
The Resource-based View as an Instance of Scientific Progress in Strategic Management
}

\begin{abstract}
Does the RBV represent a case of scientific progress? And has it emerged as the dominant approach to the analysis of competitive advantage for this reason? Conventional criteria for scientific progress, notably those of the growth of knowledge literature, are not particularly helpful for understanding this. Instead, it is argued that in order to understand why the RBV is an instance of scientific progress, we should begin from the notion that reduction is at the heart of progress in science, and that many scientists implicitly or explicitly hold this view. The RBV is a case of scientific progress because it identified theoretical mechanisms at levels lower than those that were usually investigated in strategy research prior to the RBV. Unfortunately, the micro-emphasis of the RBV gave way during the 1990s to more aggregative modes of theorizing (i.e., the capabilities approach). Thus, the RBV represents an "unfinished revolution" as there is still considerable potential to dig deeper in the deep structure of competitive advantage.
\end{abstract}

\section{Keywords}

Resource-based view, mechanisms, reductionism, competitive advantage, transaction costs, property rights.

JEL Code: L2, M1 
"Reduction is at the heart of progress in science."

- Elster (1989: 74)

\section{Introduction}

The RBV is now rather generally acknowledged as having the status of dominant perspective in the strategy field. In retrospect it may well have held this position for more than a decade. ${ }^{1}$ An impression of the dominance of the RBV may quickly be gained from inspecting the major journals in the strategy field. Thus, literally no issue of the Strategic Management Journal is published without at least one paper applying the analytical framework of the RBV, typically either in the Barney (1991) formulation or the somewhat different Peteraf (1993) formulation. A number of special journal issues, including the present one, and book volumes have been dedicated to assessing the past, present status and possible future of the perspective (Journal of Management 2001; Strategic Management Journal 2003; Management Revue 2004). Thus, it is hardly a controversial claim that the RBV is a, and very likely the, dominant approach to strategic management. This paper raises the issue of whether the RBV is also a case of scientific progress and which criteria we may employ to decide this issue. The main argument is as follows.

If we imagine ourselves placed as detached and neutral observers 15-20 years ago, surveying the landscape of strategic approaches, it would not be so obvious that the RBV would eventually achieve its now dominant status, at least if standard criteria for scientific progress were applied. Thus, the RBV failed on basic Popperian criteria (Popper 1934), in the sense that the perspective was for a long time, and with some justification, criticized for not being falsifiable (e.g., Priem and Butler 2001; Barney 2001). It failed on Lakatosian criteria (Lakatos 1970): Granted, the RBV explained competitive advantage in a novel manner'; however, competitive advantage in itself was no Lakatosian "novel fact" in the sense of a hitherto un-recognized and un-theorized feature of the World (Lakatos 1970), as differential performance has always been the main dependent variable in the strategy field. And it failed on Kuhnian criteria (Kuhn 1970), as it did not lead to the complete overthrow of previous strategic management perspectives. The RBV, then, did not really represent a clear cut case of scientific progress - at least if evaluated in terms of the mainstream theory of science literature.

\footnotetext{
${ }^{1}$ In particular, the Barney (1991) paper with its handy and easy-to-comprehend VRI (with the "O” added later) formulation of the conditions of sustained competitive advantage appears to have been particularly important for spreading the RBV gospel (Priem and Butler 2001). This paper has been cited 1501 times (Social Science Citation Index, accessed on 18 October 2005) making it one of the most cited papers in management over the last two decades.

${ }^{2}$ At least in the context of the strategy field. The indebtedness of the RBV to the Chicago-UCLA approach to price theory has often been noted, for example, by Foss (2003).
} 
The emergence and eventual dominance of the RBV is a rather complex process, interwoven with a number features that are perhaps best understood in a sociology of science framework. ${ }^{3}$ However, this does not mean that the emergence of the RBV is entirely a matter of sociological "context". On the contrary, I here want make the case that the success of the RBV is well-deserved, for the reason that it in important respects dug deeper into the "deep structure" of competitive advantage than previous approaches. Moreover, part of the reason why the RBV became influential is that this was recognized and rewarded in terms of increasing adherence to basic RBV tenets by the strategic management community. Thus, it is possible to tell a "rational" story (rather than one stressing politics, emotions, prestige, etc) about the success of the RBV in terms of influence in this community.

Of course, this story presupposes, first, that reductionism can be a way that science progresses and, second, that this is recognized in the scientific community. As this view is far from uncontroversial I briefly explain and defend it, linking it to the classic debate in social science between methodological individualists and methodological collectivists (On Scientific Progress and Reductionism). After looking at (parts of) the history of the strategy discipline in terms that make use of this progress criterion (The Evolution of Strategic Management: Levels of Analysis, Micro-foundations and Collectivism), I end by arguing that the reductionist theme is primarily represented by the RBV, but that the RBV still needs to dig even deeper than the resource-level (Concluding Discussion: The RBV as an Unfinished Revolution in Strategic Management). In sum, this paper contributes to a small but growing literature on theory of science aspects of strategic management (Godfrey and Hill 1995; Mir and Watson 2001; Powell 2001, 2003; Farjoun 2002; Arend 2003), but with a specific application (the RBV) and a distinct, novel perspective (scientific progress as the uncovering of mechanisms at deeper analytical levels).

\section{On Scientific Progress and Reductionism: The Case of Strategic Management}

\section{Theory of Science Debates in Economics and Strategic Management}

The theory of science has historically had a number of aims, although the priorities have changed quite dramatically, perhaps particularly over the last twenty years. A traditional aim has been to characterize science as a distinct field of inquiry, to describe the procedures that secure scientists privileged access to Nature's Secrets, and to identify the criteria — such as potential falsifiability

${ }^{3}$ Such as the fact that Barney and Rumelt were both interacting with economists Harold Demsetz and Armen Alchian in the context of the UCLA. The importance of these two economists for the evolution of the RBV cannot be over-estimated. I have discussed this in Foss (2000). 
(Popper 1934) — that may distinguish scientific from non-scientific arguments (i.e., the “demarcation problem”).

Another traditional activity has been the search for criteria of scientific progress, an undertaking almost wholly dominated by the so-called "growth of knowledge" literature (Popper 1934; Kuhn 1970; Lakatos 1970; Laudan 1977). In the social sciences, the growth of knowledge literature became particularly influential in economics, arguably the discipline that overall has influenced strategic management the most. Specifically, a watered down version of Popperian falsificationism in the guise of Milton Friedman's (1953) brand of instrumentalism became hugely influential in economics, and the growth of knowledge literature became relatively influential in economics in the 1970s and 1980s. Thus, a cottage industry — now very much a sunset industry — that explored various changes in economic theory in analytical terms from the growth of knowledge literature developed in the 1980s (see Backhouse 1994 for a post mortem). In the context of the strategy discipline, growth of knowledge arguments were forcefully put forward by Camerer (1985) and Balakrishnan, Montgomery and Wernerfelt (1989), that is, strategy scholars strongly influenced by economics. In particular, these scholars criticized the lack of falsifiable analytical content in strategy content research. Growth of knowledge arguments continue to be invoked in methodological discussions in strategic management (e.g., Powell 2001: 876).

In economic methodology, Imre Lakatos' methodology of scientific research programme was particularly influential. The important organizing category in Lakatos' model is "the scientific research program", which is clearly a more detailed version of Kuhn's concept of paradigm. Specifically, it should be thought of as a series of theories that comprise a continuous whole because they share some so-called "hard core propositions" and are constructed according to heuristics that are specific to the scientific research program. The research program changes by modifying propositions in the "protective belt" (the "positive heuristic" informs the researcher about how this should legitimately be done, and the negative heuristic informs him about what cannot legitimately be done), while keeping intact the hard core. This is so far a descriptive model of scientific activity. But Lakatos adds a normative dimension by introducing notions of progression and degeneration:

Let us take a series of theories, $T_{1}, T_{2}, T_{3}, \ldots$ where each subsequent theory results from adding auxiliary clauses to ... the previous theory in order to accommodate some anomaly, each theory having at least as much content as the unrefuted content of its predecessor. Let us say that such a series of theories is theoretically progressive (or 'constitutes a theoretically progressive problemshift') if each new theory has some excess empirical content over its predecessor ... Let us say that a theoretically progressive series of theories is also empirically progressive (or 'constitutes an 
empirically progressive problemshift') if some of this excess empirical content is also corroborated ... Finally, let us call a problemshift progressive if it is both theoretically and empirically progressive, and degenerating if it is not (Lakatos 1970, p.118).

By "excess empirical content" is here meant that the relevant theory puts forward some "novel fact", some hitherto unnoticed prediction, which apparently (Lakatos is not entirely forthcoming here) should be understood as predicting novel phenomenon. ${ }^{4}$

Economic methodologists gradually realized that economists were not terribly scrupulous with respect to practising the falsificationism they hailed in their rhetorical practice (Blaug 1980), and it was similarly found that it was quite hard to come up with convincing examples of Kuhnian revolutions or Lakatosian novel facts in economics (DeMarchi and Blaug 1991; Backhouse 1994; Foss 1998). As a consequence, the focus began to shift to examining the actual practice of economists, that is, to those criteria that may be inferred through the actual choices that are being made in theory-building, and away from abstract and context-independent criteria for theory choice (e.g., Mäki 1992). The wish to pass judgment on actual theory choice was also downplayed. Partly in parallel with this, the economics profession had a brief flirtation with rhetorical analysis, that is, the actual acts of persuasion that practising economists employ to convince their peers of the soundness of their arguments (McCloskey 1983). And some of the reorientation away from the growth of knowledge literature took place in tandem with and to some extent inspired by currents in the sociology of science, notably the various ("strong”, "weak") "programs" in the sociology of science (e.g., Bloor 1976). However, unlike the situation in many other social sciences, very few economists and economic methodologists have bought into the more extreme positions associated with the strong program in the sociology of science.

Strategic management is in a number of ways reminiscent of economics, not only because economics is an important foundational input in strategic management research, or because many strategic management scholars have an economics background, but also because strategic management seems to have gone through rather similar waves of methodological discussion and opinion. Early enthusiasm, mentioned above, with growth of knowledge philosophers, notably Popper, (e.g., Camerer 1985; Balakrishnan et al. 1989) gave way to more "pluralistic” positions (e.g., Bowman 1990). For example, the "rhetorical" approach of economic historian Donald MacCloskey was forcefully applied by Joe Mahoney in a string of papers in the beginning of the 1990s (e.g., Mahoney and Pandian 1992; Mahoney 1993).

\footnotetext{
${ }^{4}$ Unfortunately, “.... the notion of 'empirical content', of 'novel fact', of 'corroboration' are among the most vexing in the philosophy of science” (Rosenberg 1986, p. 135), and Hands (1991b, p.94) outright proclaims that "I have spent a great amount of time with the Lakatosian literature and I have no idea what Lakatos 'really meant' by novel facts".
} 
It is not difficult to see why strategic management scholars would be uncomfortable with growth of knowledge arguments. First, although strategic management is a very strongly empirical field, it is also clear that most strategic management researchers do not follow falsificationism in the form espoused by Popper, but rather the “ ... statistical view of testing that accepts that neither refutation nor confirmation can ever be final, and that all we can hope to do is to discover on the basis of finite amounts of imperfect knowledge what is the balance of probabilities among existing hypotheses" (Lipsey 1966: 184). Second, the Kuhnian and Lakatosian schema seem difficult to apply to a field that does not go back more than at most fifty years. It is not clear that there are in any meaningful sense Kuhnian paradigms or Lakatosian scientific research programmes in strategic management. Moreover, it is unclear what are the Lakatosian "novel facts" in strategic management research (perhaps depending on how exactly that enigmatic concept is defined). To be sure, "competitive advantage," whether sustained or not, hardly qualifies as a novel fact, as the recognition that some firms are more successful than others on a sustained basis certainly qualifies any strategic management approach, and indeed the field itself.

Still, strategic management scholars continue to vigorously debate methodological issues and the subject seems to have increased in popularity recently. Thus, Godfrey and Hill (1995) applied the philosophy debate on how to deal with the problem of unobservables to strategic management; Powell (2001) explored philosophical aspects of the link between competitive advantage and financial performance that is foundational to the strategic management field; Mir and Watson (2000) argued in favour of a constructivist approach to understanding the evolution of the strategic management field, and Kwan and Tsang (2001) countered with making the same point on behalf of critical realism. However, what methodologically inclined strategic management scholars seem to have given up discussing the issue of what constitutes scientific progress in the field. In contrast, I here propose to revitalize that discussion in terms of proposing that one important way (certainly not the only one) in which strategic management progresses as a scientific field is by means of performing analytical reduction, that is, showing how phenomena on a given level of analysis is really constituted by the action and interaction of entities, ultimately human beings, at levels lower down.

\section{Reduction as Progress}

I want to here propose that many practising social scientists, particularly economists (cf. also Mäki 2001), but also many strategic management scholars are "moderate reductionists," and that they tend to associate scientific progress with the application of a reductionist research strategy. ${ }^{5} \mathrm{By}$

\footnotetext{
${ }^{5}$ It is very likely that disciplinary background plays an important role here, strategic management scholars with more of an economics background arguably being more disposed towards reductionism for disciplinary reasons than strategic management scholars with more of a sociology background.
} 
reductionism is here understood the explanatory position that the best understanding of a complex, and in social science: collective-level, phenomenon “... should be sought at the level of structure, behaviour and laws of its component parts plus their relations” (Silberstein 2002: 81). It entails a search for “deep structure” underneath aggregate phenomena (Williamson 1996).

On the criterion of reduction as progress, a body of knowledge (whether a theory, research program, paradigm, research tradition, etc. etc.) makes progress when a novel analytical reduction is performed, that is, when one or more explanatory mechanisms, constructs, etc. that were hitherto blackboxed are opened up and addressed in terms that are congenial to the other elements of the body of knowledge (i.e., a purely psychological explanation of preferences is not scientific progress within economics; although it does open up the black box of preferences, this is not done in economic terms). Such an improved understanding is synonymous with scientific progress, because it allows us to better grasp the real generative mechanisms that produce events (Bhaskar 1978). ${ }^{6}$

Reductionism has generated much heated controversy, including controversy in strategic management. For example, Bourgeois (1984: 586) argued that “... reductionism eliminates much of the richness that characterizes the strategic management process.” As the position here is the exact opposite - we need more reductionism in strategic management research to increase the richness of the field - it is advisable to be explicit about what reductionism does and does not entail.

Thus, the qualifier "moderate" in "moderate reductionism" here indicates that the aim is not to pursue the kind of charicature reductionism well known from debates in natural science:

An extreme and classical kind of reductionism holds that all laws governing the behaviour of complex objects should be deducible from the laws of lower-level science and thus, ultimately, the laws of all sciences should be deducible from those of particle physics" (Dupré 2001: 309).

Applied to strategic management such a view would imply that competitive advantage be reduced to the genetic endowment of firm founders (and, indeed, ultimately to the laws of particle physics). Furthermore, reductionism in social science is sometimes taken to mean that all explanation must make reference to the full set of concrete actions, preferences, beliefs, etc. of concrete agents when trying to explain a phenomenon on the social domain. Obviously, this is very often not feasible because of the sheer number of interacting agents and the complexity of their interaction - a

\footnotetext{
${ }^{6}$ Although Elster's (1989: 74) dictum that "[r]eduction is at the heart of progress in science," would likely be accepted by many scientists and philosophers, I am not aware of any sustained theory of science discussions of reduction(ism) as (a) progress (strategy).
} 
problem that is occasionally referred to as "Cournot's Problem” (e.g., Davis 2003). Whatever that may be, ${ }^{7}$ no such extreme reductionism is advocated here.

Rather, "moderate reductionism” entails a sustained attempt to identify and theorize the causal social mechanisms - the "cogs and wheels” (Elster 1989: 3) - that generate and explain observed associations between events. This view is consistent with scientific and methodological realism (Harré 1970; Bhaskar 1978; Foss 1994). It is, however, different from the traditional covering-law model of explanation of Carl Hempel and others, because the covering-law model does not imply an insistence on identifying genuine causality.

The reductionism advocated here seeks to eschew explanatory black boxes in principle. However, sometimes a case can be made for some degree of black box explanation. One reason is disciplinary: For example, most economists want to treat tastes as black boxes, because not doing so would take them into entirely unfamiliar psychological territory. Strategic management scholars may agree on this point. Another reason for allowing some black boxes to enter explanation is explanatory parsimony, ultimately implied by bounded rationality (Hedström and Swedberg 1998:12). As Lewis (1986: 214) explains,”[a]ny particular event that we might wish to explain stands at the end of a long and complicated causal history. We might imagine a world where causal histories are short and simple; but in the world as we know it, the only question is whether they are infinite or merely enormous.” This problem is clearly akin to "Cournot's problem.”

Luckily, it is simply not always necessary to seek and perform "rock-bottom explanation” or to refer to all individual level facts for an explanation to be valid. For example, the strategic management scholar who is cognizant of economics knows that under competitive conditions, decision-makers in firms only have a very limited feasible behavioural repertoire. If they do not choose an element of this set, they will not survive. Thus, although there is no break with the ontological position that only individuals can choose, our strategic management scholar pragmatically recognizes that a structure (i.e., competitive conditions) can substitute in an explanatory sense for a much more complicated explanation involving individual action and interaction (for a related approach, see Koppl and Langlois 1991; Satz and Ferejohn 1994). However, being a proper reductionist, he knows that such a "structural” story is at best a reduced form explanation, or, if you like, shorthand.

Economists and strategic management scholars perform somewhat related explanatory operations when they construct firm-level arguments. Thus, to involve the argument in an explanation that a firm has a strategy or acts in a certain way is essentially shorthand for a complex set of underlying

\footnotetext{
${ }^{7}$ As an objection to reductionism, the argument seems to be a red herring, as Cournot's problem does not rule out the possibility of explaining in terms of tractable models. The problem may be one of empirical application of a reductionist research strategy, but it is not one of theory and model-building.
} 
individual actions and interactions. However, the descriptive accuracy of this shorthand is will depend on, for example, the transaction costs that characterize the international organization of the firm: If internal transaction costs are low (so that communication between organizational members can take place and side-payments are possible), it makes sense to speak of organizational members acting as a unified body, because goals and incentives can be aligned with an overall strategy (Milgrom and Roberts 1992).

\section{Individualism and Collectivism}

In a social science context, "reductionism" is unavoidably associated with "methodological individualism.” Notably, for more than a hundred years, economics (e.g., Menger 1883; Hayek 1952; Arrow 1951; Dosi 1995), sociology (e.g., Durkheim 1962; Lazarsfeld and Menzel 1970; Coleman 1990) and the philosophy of science (Popper 1957; Satz and Ferejohn 1994; Kincaid 1997) has witnessed a debate about whether individuals ("micro") or social collectives ("macro") have explanatory primacy (Dosi 1995; Felin and Foss 2005). ${ }^{8}$ Reductionists have taken the former position. $^{9}$

In its most extreme form, methodological individualism asserts that in explanations of social phenomena reference is allowed only to individuals, their properties and their (inter)actions. Thus, at no point in the explanation can reference be made to supra-individual entities as in any way acting as causal agents. No "shortcuts" by making reference to aggregates are allowed anywhere in the explanation. On this program, explaining, for example, "the strategy of a firm” must always involve making reference to the mental states of all relevant organizational stakeholders. ${ }^{10}$ Many methodological individualists do not espouse this strong form, which will very often run into Cournot's problem. For example, Agassi (1960) argues that reference to institutions, clearly a collective concept, can be permitted in social science explanation, and many methodological individualists would argue - along the lines indicated in the above example of producers under competitive conditions - that reference to collective concepts is permissible, and sometimes necessary as a sort of explanatory short-hand. ${ }^{11}$ In the context of strategic management, those who

\footnotetext{
${ }^{8}$ See Udehn (2001) for a recent overview, or O’Neill (1973) for a compilation of key readings.

${ }^{9}$ For a survey and discussion for management scholars, see Abell, Felin and Foss (2005).

10 Clearly, this program will often not be completely practicable for empirical reasons: It is usually impossible to obtain the necessary empirical information that is necessary to perform such a fine-grained explanation. This problem is sometimes referred to as “Cournot's Problem” (e.g., Davis 2003). Of course, Cournot's problem does not invalidate the possibility of building an individualistic model that explains the relevant phenomenon.

${ }^{11}$ Of course, real world actors themselves also make use of collectives in this manner, for example, when arguing that "France won the international soccer cup," or "Russia invaded Afghanistan in 1979" etc. Moreover, real world actors are influenced by collective entities, such as the aggregate price level (Levy 1984) because such entities usefully aggregate information (Lucas 1972).
} 
otherwise subscribe to methodological individualism may allow for occasional mention of the collective concept of capabilities as a handy explanatory shorthand. However, all methodological individualists insist that ultimately collective phenomena must be reduced to and explained in terms of individuals, that is, individual endowments, intentions, desires, expectations, and goals (cf. Hayek, 1952; Elster, 1989). Thus, the methodological individualist strategy scholar will not accept as satisfactory the use of the notion of capabilities until the individual level foundations of this concept have been clarified and he will use the term with reluctance. ${ }^{12}$

In contrast, methodological collectivism starts assuming that collectives are fundamentally independent from individuals and can therefore be taken as "primitives" in social science explanation. That is, collectives such as organizations, and "social facts" such as institutions, culture and capabilities serve as the primary independent variables determining individual and collective behaviour and outcomes (e.g., DiMaggio and Powell 1991: 8). The broad argument is that structure and institutions are prior to individuals in influencing (and even determining) choice sets and behaviour. In general, individual-level explanation is rejected in favour of collective explanation. As Felin and Hesterly (2005) notes such an argument is espoused in, for example, the view that organizations are "strong situations" (Davis-Blake and Pfeffer 1989).

In terms of the earlier emphasis on opening up black boxes and uncovering causal mechanisms, it is clear that methodological individualists and methodological collectivists differ strongly with respect to which boxes need to be opened and which mechanisms deserve emphasis, and perhaps even which mechanisms exist. In other words, ontological positions are very likely to accompany methodological positions. Thus, a hardcore methodological individualist will deny any top-down causation and insist that all that matters is bottom-up causation (i.e., from individuals to collectives). A moderate methodological individualist may accept that at least metaphorically (cf. the earlier notion of explanatory shorthand) institutions exert influence on individual behaviour, for example, in the sense that "they" structure incentives and therefore impact behaviour (Boudon 1998). Hardcore collectivists may argue that causal relations that operate wholly on the collective level have real existence and are not just explanatory shorthand. ${ }^{13}$ However, this does not mean that this mode of explanation cannot be discerned in the practice of strategic management scholars. In actual fact, it can. Thus, in the following, I argue that the strategy field has in fact been dominated by collective

\footnotetext{
${ }^{12}$ Will he accept that capabilities exist? As I see it, the methodological individualist strategic management scholar may admit ontological status to capabilities in the sense that acknowledging that capabilities describe patterns of specialization and co-specialization of firm members' knowledge and actions that are specific to a given firm.

${ }^{13}$ Although it may be doubted whether this position is actually explicitly defended (it simply can't be defended!) by any serious social scientist or management scholars. However, Felin and Hesterly 2005) and Felin and Foss (2005) present some examples of reasoning that comes dangerously close.
} 
level explanation for most of its history. However, the RBV is an approach that (along with, e.g., transaction cost and property rights perspectives) is at least in principle consistent with a reductionist research methodology.

\section{The Evolution of Strategic Management:}

\section{Levels of Analysis, Micro-foundations and Collectivism}

\section{Scientific Progress in the Strategic Management Field}

Has the strategic management field made scientific progress? Obviously, how that question is answered depends on which criteria are applied and even on how these criteria are interpreted. On the basis of criteria essentially borrowed from economics, Camerer (1985) concluded that strategic management had not made any substantial theoretical progress. In particular, he stressed conventionalist criteria such as the "coherence" of the theoretical structure. Mahoney (1993) argued that the alleged "coherence” may effectively translate into suppressing (necessary) diversity. On the basis of what seems to be an instrumentalist criterion Arend (2003: 283) argued that "If .... science is defined by an ability to predict and control the dependent variables of interest then strategy research cannot ultimately fare well. Perhaps a new definition is needed to provide a fairer measure of progress in strategy research.” While Arend may pass unnecessarily harsh judgment, the argument here is that his call for new criteria for assessing scientific progress in the strategic management is well taken. One such new criterion is analytical reduction, as has just been suggested. Analytical reduction is often performed by moving down a level of analysis.

\section{Levels of Analysis}

As Hackman (2003: 905) notes, "[r]egardless of the level of analysis at which we begin, we like to move to the next level for our explanations.” For the practising social scientist that level, Hackman explains by means of examples, typically lies lower down, not up. ${ }^{14}$ However, it is not the case that the strategic management field has exhibited a natural tendency to adopt increasingly reductionist or micro-oriented explanations. On the contrary, the field has, taken as a whole demonstrated a preference for supra-individual levels of analysis, whether these be the capabilities/competencies/core competencies/dynamic capabilities, firm, group, or industry levels. Of course, there is nothing surprising in this, given that the key dependent variables in strategic management research have typically been located at the firm level. However, to work at levels of analysis that are higher than that of the individual does not, of course, rule out the need for establishing micro-foundations for such aggregate work (i.e., the analytical convenience or necessity

\footnotetext{
${ }^{14}$ Hackman, however, comes out in favour of a strategy of temporarily "bracketing" the focal level of analysis and focusing attention on the level immediately below and immediately above this level to gain increased understanding
} 
of supra-individual levels of analysis does not make obviate micro-foundations). However, the efforts to build explicit micro-foundations have been very few. Therefore, there have also been very few attempts to seriously reconcile micro and macro-levels, ${ }^{15}$ in spite of much recent attention being paid to "levels issues," "multiple level analysis" and the like (e.g., Danseareu et al., 1999) in management in general.

There are various reasons why this sort of inquiry has so far been largely absent from strategic management. At the most basic level, strategic management is still a young field: No or few fields begin in a multi-level mode and in social science micro-foundations do not necessarily come first. ${ }^{16}$ Another reason is that in an inherently applied and practical discipline, implicit consensus may arise that issues of micro-foundations and of bridging levels are best left at the level of the base disciplines (e.g., psychology, economics, sociology inquiry (Abell, Felin and Foss 2005. A third possible reason is that strategic management may be inherently pluralistic (Mahoney 1993; Mahoney and Pandian 1993) and this precludes building specific micro-foundations (Felin and Foss 2005). Whatever all that may be, strategic management has usually been characterized by collective level theorizing (see also Felin and Hesterly 2005), as will be discussed next.

\section{Strategic Management in the Aggregate Mode}

As an analytical enterprise, strategic management began very much in the aggregate mode. Early thinking coming out of the Boston Consulting Group stressed firm-level learning curve advantages with no attention being paid to the underlying intra-organizational generative processes of individual action and interaction that are ultimately responsible for the learning-curve phenomenon. Research inspired by the Profit Impact of Market Strategy project begun in the mid-nineteen sixties at General Electric and expanded upon by the Management Institute at Harvard from the beginning of the 1970s entailed a search for reduced form correlations between profit variables and various potential independent variables that defined an aggregative style of theorizing that is still very much present in the field. The focus of the PIMS project arguably also helped to pave the way for the field's perhaps first serious analytical breakthrough, namely Porter's (1980) industry analysis/positioning approach.

Transferring industrial organization economics to the strategy field, Porter's approach placed literally all of the explanatory burden on the aggregate characteristics of the environment, as captured in the famous " 5 forces." The firm as has so often been observed is completely blackboxed in this

\footnotetext{
${ }^{15}$ Usually, the industry and the firm levels are "aligned" through application of the SWOT framework, the SW representing the firm level and the OT the industry level. For a forceful critique of the soundness of this, see Makadok (2005).

${ }^{16}$ Even economics began in the aggregate mode. Explicit microeconomics only really arrived with the marginalist revolution(s) of the 1870s, that is, about a hundred years after Adam Smith's classic (and two hundred years after William Petty).
} 
approach. Managers are mentioned, but only as the agents that have to carry out the analysis of industries and position the firm in the chosen industries. Their skills at doing this are presumably the main source of competitive advantage. Of course, as a practising economist Porter cannot be expected to have any particular sympathy for methodological collectivism. And his industry analysis does not harbour any ontological pretensions with respect to the existence of industries as anything other but producers that recognize that their products are close or relatively close substitutes. Indeed, as Porter (1980) himself stresses, the five forces approach used as a strategic tool is first and foremost a first cut at organizing information of relevance to the firm. While starting from this cut, more sophisticated strategic analysis must deal with strategic groups and mobility barriers, with pricing tactics, and the like.

In fact, later strategic management work that builds from industrial organization economics has typically dealt with exactly these kind of more fine-grained issues. As a result, some of the somewhat fuzzy collective categories that loom so large in Porter's early work disappear. Thus, instead of anonymous "forces" now come well-specified cooperative and non-cooperative games with (respectively) buyers/suppliers/complementors and competitors (Ghemaway 1998; Brandenburger and Nalebuff 1996) where the players are clearly identified, and - at least in the case of noncooperative games — their interaction is explicitly modelled. The case of the Porter approach nicely illustrates how an aggregative approach that places all of the informational burden on the analytical level immediately above the focal firm sacrifices informational content. Thus, the industry analysis/positioning has nothing in itself to say about firm-level competitive advantage.

\section{Towards Micro - and Back to Collectives and Collectivism}

The RBV has very often been portrayed as an approach that supplied the missing pieces, specifically the analysis of (firm-level) competitive advantage, ${ }^{17}$ by taking an explicit focus on the resources that firms control. It is often informally seen as an instance of scientific progress because it treated a hitherto untheorized set of mechanisms, that is, the links from resources to competitive advantage and in turn to performance. The other side of that coin is that the RBV was reductionist in the sense that it literally dug deeper than rival perspectives by placing the primary explanatory burden on the resources controlled by a firm rather than on industry structure and competitive interaction. The individual resource would, at least on first inspection, seem to lie on a substantially lower level of analysis than the industry, the group or the firm. Thus, the RBV would seem to be well suited to exploring, for example, how individual employees contribute to value creation and how created value is distributed as a result of bargaining processes among the various stakeholders whose cooperation

\footnotetext{
${ }^{17}$ Such a reading stresses (positive) complementarity between the Porter approach and the RBV. That this reading may be inconsistent is forcefully argued by Makadok (2005).
} 
takes place under the legal shell represented by the firm (Wernerfelt 1989). This potential for microanalysis was, however, sidetracked for a long time, until the important recent work of Coff (1999) and Lippman and Rumelt (2003a\&b).

It is quite arguable that one of the reasons why the RBV gained so much success is exactly the feature of digging deeper. Not only may this has been recognized as an independent achievement (as the above suggests that indeed it should), but it also had the advantage of bringing the view in contact with organizational theory (in a broad sense, including organizational economics and organizational behaviour), human resource management, research on ICT and much other strategically relevant research that was hard to link to the more aggregative Porter approach.

However, as time unfolded, several things happened that implied that strategic management did not really fully release the potential for micro-analysis that the advent of the RBV signalled. First, standard definitions of a "resource" did not take an explicit micro-perspective. Thus, Barney (1991) defined a resource inclusively as "anything that may be thought of as an advantage to a firm." Clearly, this might conceivably encompass organization-level, collective resources, such as capabilities, culture and the like. Dierickx and Cool's (1989) extremely influential analysis was widely interpreted as (fallaciously) implying that "stand-alone” resources acquired on strategic factor markets could not in general be expected to give rise to competitive advantage simply because they were traded. Whatever we may think of the soundness of this conclusion (and for the contrary view, see Barney 1986 and recently Denrell, Fang and Winter 2003), the perceived force of its logic directed attention to "socially complex," "collectively held" resources, such as the "core competencies" or "capabilities” that were gaining currency in the beginning of the 1990s. ${ }^{18}$

There was a move back to the collective level, as strategy scholars increasingly converged on organizational capabilities as a key construct (Eisenhardt and Martin, 2000; Winter, 2003). Indeed, the organizational capabilities approach may now be the predominant way of thinking about heterogeneity in strategic management. Sustained competitive advantage, a firm-level phenomenon, is now directly explained in terms of capabilities, competencies, etc., that is, in terms of other firmlevel phenomena. Obviously, this is blatant methodological collectivism (Felin and Foss 2005; Felin and Hesterly 2005).

\section{Concluding Discussion: The Resource-based View}

as an Unfinished Revolution in Strategic Management

\footnotetext{
${ }^{18}$ At the AoM meetings in 2004 at which Felin and Foss (2005) was presented, several members of the audience argued that the emphasis in that paper on micro-foundations were not relevant to strategic analysis, because all sustainable heterogeneity was located at the collective level.
} 
The RBV is an extremely flexible approach. It is so flexible that although originally inspired by economics and rather explicitly built in an attempt to establish more secure micro-foundations for strategic management (e.g., Lippman and Rumelt 1982; Wernerfelt 1984; Barney 1986), it can also encompass collectivist strands in strategic management that are more inspired by the mode of explanation found in sociology or social psychology than in economics. The trick to include capabilities, dynamic capabilities, culture, collective cognition, etc. among the set of potentially strategic resources and analyze them using the standard RBV apparatus (i.e., Barney 1991; Peteraf 1993) is a rather simple one. Thus, in contemporary strategic management notions of capabilities would seem to merge seamlessly with RBV analysis. ${ }^{19}$

However, as Felin and Foss (2005), Felin and Hesterly (2005) and Abell, Felin and Foss (2005) argue, the collectivism that is characteristic of the recent emphasis on capabilities comes at a significant cost. Among the many problems they highlight is that the absence of micro-foundations in the capabilities approach means that it is difficult to account for the emergence of and change in capabilities (except in terms of other capabilities). The problem of value appropriation (Lippman and Rumelt 2003b) is also sidestepped, because the bargaining games between individual players that result in created value being appropriated disappears out of sight because of the aggregative focus in the capabilities approach. And the aggregative focus means that self-selection explanations of firm heterogeneity (certain kinds of heterogeneous individuals self-selecting into certain environments) are ruled out a priori as an explanation of heterogeneity, as Felin and Hesterly (2005) argues.

To the extent that the advent of the RBV in the strategic management field represented a revolutionary attempt to step down the analytical ladder in terms of at which levels the sources of competitive advantage are located, that revolution is now halted; it has in fact given way to the capabilities counter-revolution.

However, there are signs that the pendulum might swing yet again. Thus, in a string of contributions, Russell Coff (e.g., Coff 1997, 1999) has argued that attention be paid to internal processes of bargaining between key stakeholders in the firm, and has taken important steps towards a conceptualization of this. The importance of understanding appropriation lies not just in understanding the phenomenon itself, but also in understanding how appropriation feeds back on value creation, a key point in organizational economics (e.g., Hart 1995), but one that is presently neglected in strategic management. Lippman and Rumelt (2003b) exploit economic bargaining theory in order to comprehend this bargaining process. Lippman and Rumelt (2003a) argue that taking appropriation seriously has important implications for many of the most dearly held notions in

\footnotetext{
${ }^{19}$ For a contrary view that the RBV and the (dynamic) capabilities perspective are in fact widely different, ontologically, theoretically and methodologically, see Stoelhorst (2005).
} 
strategic management. Among other things, they point out that there is no entity, called "the firm," that appropriates a residual known as "profit" — all revenues are paid to factors. Makadok and Barney (2001) carefully model firms' information acquisition strategies in an attempt to understand the micro-dynamics of strategic factor markets. Foss and Foss (2005) take an even more microoriented approach and focuses not on resources, but on property rights to attributes of resources (e.g., uses and functionalities of individual resources). They show that this gives considerable added insight into resource value, in addition to establishing a direct link to transaction cost economics. All of these contributions represent evidence that "digging deeper” does result in new insight

That the RBV is likely to develop by an increasing micro-focus was emphasized explicitly Jay Barney (2001) in his rebuttal to Priem and Butler (2001). Thus, Barney (2001: 52-54) singles out a number of areas where the RBV is currently deficient, specifically "strategic alternatives," "rent appropriation" and "strategy implementation." The first area calls for increased understanding on entrepreneurship and creativity, an undertaking unavoidable involving the level of the individual. The second area, Barney notes, has been advanced by the work of Coff (1999) and others, but there are still many un-resolved issues, such as how different stakeholders come to enjoy different bargaining positions, why the value of such positions isn't absorbed in the investments needed to create them, etc., issues that would seem to call for making very explicit assumptions about individual agents. Thirdly, strategy implementation raises micro-level issues of the kind treated in agency and organizational behaviour theory. Thus, all of the three primarily pressing issues in the RBV intimately involve micro-foundations, and if the resource-based research community agrees with Barney, future progress in the RBV will come from building micro-foundations in the course of examining those strategic issues that require a micro approach. 


\section{References}

Abel, Peter, Felin, Teppo and Nicolai Foss. 2005. "Individuals and Organizations: Towards a MicroFoundations Project for Routines and Capabilities”, forthcoming.

Agassi, Joseph. 1960. “Methodological Individualism”, British Journal of Sociology 11: 244-70.

Arend Richard J. 2003. "Revisiting the logical and research considerations of competitive advantage”, Strategic Management Journal 24: 279-284.

Arrow, K.J. 1951. Social choice and individual values. New York: Wiley \& Sons.

Backhouse, Roger A., ed. 1994. New Directions in Economic Methodology, London: Routledge.

Balakrishnan, Srinivasan, Cynthia A Montgomery, and Birger Wernerfelt. 1989. "Strategy Content and the Research Process: A Critique and Commentary,” Strategic Management Journal 10: 189-197.

Barney, Jay B. 1986. ”Strategic Factor Markets”, Management Science 32: 1231-1241.

Barney, Jay B. 1991. "Firm Resources and Sustained Competitive Advantage”, Journal of Management 17: 99-120.

Barney, Jay B. 2001. 'Is the Resource-based 'View’ a Useful Perspective for Strategic Management Research? Yes,” Academy of Management Review 26: 41-57.

Bhaskar, Roy. 1978. A Realist Theory of Science. 2nd ed., Brighton: Harvester.

Blaug, Mark. 1980. The Methodology of Economics, Cambridge: Cambridge University Press.

Bloor, David. 1976. Knowledge and Social Imagery. London. Routledge.

Boudon, Raymond. 1998. "Social Mechanisms without Black Boxes," in Peter Hedström and Richard Swedberg, eds., Social Mechanisms: An Analytical Approach to Social Theory. Cambridge: Cambridge University Press.

Bourgeois, L.J. 1984. “Strategic Management and Determinism,” Academy of Management Review 9: 586-596.

Bowman, Edward H. 1990. "Strategy Changes: Possible Worlds and Actual Minds," in J.F. Frederickson, ed. Perspectives on Strategic Management, New York: Harper.

Brandenburger, Adam M. and Barry J. Nalebuff. 1995. "The Right Game: Use Game Theory to Shape Strategy”, Harvard Business Review, 73: 57-71

Camerer, Colin. 1985. "Redirecting Research in Business Policy and Strategy," Strategic Management Journal 6: 1-15. 
Coff, Russell. 1997. "Human Assets and Management Dilemmas: Coping With Hazards on the Road to Resource-based Theory,” Academy of Management Review 22: 374- 402.

Coff, Russell. 1999. “When Competitive Advantage Doesn’t Lead to Performance: Resource-based Theory and Stakeholder Bargaining Power,” Organization Science 10: 119- 133.

Coleman, James S. 1990. Foundations of Social Theory. Cambridge (Mass.)/London: The Belknap Press of Harvard University Press.

Dansereau, Fred, Yammarino, Francis J, and Jeffrey C. Kohles. 1999. "Multiple levels of analysis from a longitudinal perspective: Some implications for theory building”, Academy of Management Review, 24: 346-357.

Davis, John B. 2003. The Theory of the Individual in Economics: Identity and Value. London: Taylor and Francis.

Davis-Blake, Allison and Jeffrey Pfeffer. 1989. “Just a Mirage: The Search for Dispositional Effects in Organizational Research,” Academy of Management Review, 14: 385-400.

Denrell, Jerker, Christina Fang, and Sidney G. Winter. 2003. "The Economic of Strategic Opportunity.” Strategic Management Journal 24: 977-990.

Dierickx, Ingemar and Karel Cool. 1989. “Asset Stock Accumulation and the Sustainability of Competitive Advantage,” Management Science 35: 1504-1511.

DiMaggio Paul and Walter W. Powell. 1991. The New Institutionalism in Organizational Analysis. Chicago: University Chicago Press.

Dosi, Giovanni. 1995. "Hierarchies, Markets and Power: Some Foundational Issues on the Nature of Contemporary Economic Organizations”, Industrial and Corporate Change 4: 1-19.

Dupré, John. 2001. “Economics without Mechanism,” in Uskali Mäki, ed. 2001. The Economic World View. Cambridge: Cambridge University Press.

Durkheim, Emile. 1962. The Rules of the Sociological Method. Glencoe, Ill.: Free Press.

Eisenhardt, Kathleen M. and Jeffrey A. Martin. 2000. “Dynamic capabilities: what are they?”, Strategic Management Journal, 21: 1105-1121.

Elster, Jon. 1989. Nuts and Bolts for the Social Sciences. Cambridge: Cambridge University Press.

Farjoun, Moshe. 2002. "Towards an Organic Perspective on Strategy" Strategic Management Journal 23: $561-594$.

Felin, Teppo and Nicolai Foss. 2005. "Strategic Organization: a Field in Search of Microfoundations,” forthcoming in Strategic Organization. 
Felin, Teppo and William S. Hesterly. 2005. "The Knowledge-Based View, Heterogeneity, and the Individual: Philosophical Considerations on the Locus of Knowledge," forthcoming in Academy of Management Review.

Ferejohn, John and Debra Satz. 1994. ""Rational Choice and Social Theory", Journal of Philosophy, 91: 71-87.

Foss, Nicolai J. 1994. "Realism and Evolutionary Economics”. Journal of Social and Biological Systems 17: 21-40.

Foss, Nicolai J. 1998. “The New Growth Theory: Some Intellectual Growth Accounting”, Journal of Economic Methodology 5: 223-246.

Foss, Nicolai J. 2000. "Equilibrium and Evolution: The Conflicting Legacies of Demsetz and Penrose,” in Nicolai J Foss and Paul L. Robertson, eds. Resources, Technology, and Strategy. London: Routledge.

Foss, Kirsten and Nicolai J. Foss. 2005. "Value and Transaction Costs: How Property Rights Economics Furthers the Resource-based View,” Strategic Management Journal, 26: 541-553.

Friedman, Milton. 1953. "The Methodology of Positive Economics,” in idem. 1953. Essays in Positive Economics, Chicago: University of Chicago Press.

Ghemawat, Pankaj. 1998. Games Business Play: Cases and Models. Cambridge: The MIT Press

Godfrey, Paul C. and Charles W. L. Hill. 1995. "The Problem of Unobservables in Strategic Management Research,” Strategic Management Journal 16: 519-533.

Hackman, J. Richard. 2003. "Learning More by Crossing Levels: Evidence from Airplanes, Hospitals and Orchestras,” Journal of Organizational Behavior 24: 905-922.

Hands, D. Wade. 1991. “The Problem of Excess Content: Economics, Novelty, and a Long Popperian Tale,” in Neil de Marchi and Mark Blaug, eds. Appraising Economic Theories: Studies in the Methodology of Research Programs, Aldershot: Edward Elgar.

Harré, Rom. 1970. The Principles of Scientific Thinking. London: Macmillan.

Hart, Oliver. 1995. Firms, Contracts and Financial Structure. Oxford: Oxford University Press.

Hayek, Friedrich A. von. 1952. The Counter Revolution of Science. Chicago: University of Chicago Press.

Hedström, Peter and Richard Swedberg, eds. 1998. Social Mechanisms: An Analytical Approach to Social Theory. Cambridge: Cambridge University Press.

Kincaid, Harold. 1997. Individualism and the Unity of Science: Essays on Reduction, Explanation and the Special Sciences. Oxford: Rowman and Littlefield Publishers, Inc 
Koppl, Roger and Richard N. Langlois. 1991. "Fritz Machlup and Marginalism: A Reevaluation,” Methodus 3: 86-102.

Kuhn, Thomas. 1970. The Structure of Scientific Revolutions. Chicago: University of Chicago Press.

Kwan Kai-Man and Eric Tsang. 2001. "Realism and constructivism in strategy research: a critical realist response to Mir and Watson”, Strategic Management Journal, 22: 1163-1168

Lakatos, Imre. 1970 "Falsification and the methodology of scientific research programmes", in Imre Lakatos and Alan Musgrave, (eds.) Criticism and the Growth of Knowledge. Cambridge: Cambridge University Press, 91-196.

Laudan, Larry. 1977. Progress and its Problems: Toward a Theory of Scientific Growth. London: Routledge.

Lazarsfeld, P.F. and P. Menzel. 1960. "On the relation between individual and collective properties” In: Etzioni, A. (ed.), Complex organizations: a sociological reader. New York: Holt, Rinehart and Winston.

Levy, David. 1984. "Testing Stigler's Interpretation of "The Division of Labor is Limited by the Extent of the Market", Journal of Industrial Economics, 32: 377-389.

Lewis, David. 1986. Philosophical Papers. Oxford: Oxford University Press.

Lippman, Steven A. and Richard P. Rumelt. 1982. "Uncertain Imitability: An Analysis of Interfirm Differences Under Competition,” Bell Journal of Economics 13: 418-438.

Lippman, Steven A. and Richard P. Rumelt. 2003a. "A Bargaining Perspective on Resource Advantage,” Strategic Management Journal 24: 1069-1086.

Lippman, Steven A. and Richard P. Rumelt. 2003b. "The Payments Perspective," Strategic Management Journal 24: 903-927.

Lipsey, Richard. 1966. An Introduction to Positive Economics. London: Weidenfeld and Nicholson.

Lucas, Robert E. 1972. "Expectations and the Neutrality of Money,” Journal of Economic Theory 4: 103-124.

MacCloskey, Donald. 1983. “The Rhetorics of Economics,” Journal of Economic Literature 21: 481517.

Mahoney, Joseph T. and J. Rajendran Pandian. 1992. "The Resource-Based View within the Conversation of Strategic Management”, Strategic Management Journal 13: 363-380.

Mahoney, Joseph T. 1993. "Strategic Management and Determinism: Sustaining the Conversation," Journal of Management Studies 30: 173-191. 
Makadok, Richard and Jay B. Barney. 2001. "Strategic Factor Market Intelligence: an Application of Information Economics to Strategy Formulation and Competitor Intelligence,” Management Science 47: 1621-1638.

Makadok, Richard. 2005. "The Competence-Collusion Puzzle and the Four Theories of Profit: Why Good Resources Go to Bad Industries,” Working Paper.

Mäki, Uskali. 1992. “On the Method of Isolation in Economics,” Poznan Studies in the Philosophy of the Sciences and the Humanities 38: 147-168.

Mäki, Uskali. 2001. “The Way the World Works (www): Towards an Ontology of Theory Choice,” idem. 2001. The Economic World View. Cambridge: Cambridge University Press.

Marchi, Neil de and Mark Blaug, eds. 1991. Appraising Economic Theories: Studies in the Methodology of Research Programs, Aldershot: Edward Elgar.

Menger, Carl. 1883. Investigations into the Method of the Social Sciences with Special Reference to Economics, Leipzig. English translation (1985) Louis Schneider (ed.), New York: New York University Press

Milgrom, Paul J. and John D. Roberts. 1992. Economics, Organization, and Management. New York: Prentice Hall.

Mir, Raza and Andrew Watson. 2000. "Strategic management and the philosophy of science: the case for a constructivist methodology”, Strategic Management Journal 21: 941 - 953.

Mir, Raza and Andrew Watson. 2001. "Critical realism and constructivism in strategy research: toward a synthesis”, Strategic Management Journal 22: 1169 - 1173.

O'Neill, J. (ed.) 1973: Modes of Individualism and Collectivism. London: Heinemann.

Peteraf, Margaret A. 1993. "The Cornerstones of Competitive Advantage: A Resource-Based View”, Strategic Management Journal 14: 179-191.

Popper, Karl R. 1934. The Logic of Scientific Discovery. Vienna: Springer.

Popper, Karl R. 1957. The Poverty of Historicism. (Reprint 1999). London: Routledge.

Porter, Michael E. 1980. Competitive Strategy. New York: Free Press.

Powell, Thomas. 2001. “Competitive Advantage: Logical and philosophical considerations” Strategic Management Journal 22: 875-888.

Powell, Thomas. 2003. “Strategy without ontology”, Strategic Management Journal 24: 285 - 291

Priem, R. L. and Butler, J. E. 2001. "Tautology in the Resource-Based View and the Implications of Externally Determined Value: Further Comments,” Academy of Management Review 26: 5765. 
Rosenberg, Alexander. 1986. "Lakatosian Consolations for Economics”, Economics and Philosophy, 2:127-39.

Silberstein, Michael. 2002. "Reduction, Emergence and Explanation," in Peter Machamer and Michael Silberstein, eds. The Blackwell Guide to the Philosophy of Science. Oxford: Blackwell Publishers.

Stoelhorst, Jan-Willem. 2005. "Why the Resource-based and Dynamic Capabilities Views Defy Integration, "unpublished paper.

Udehn, Lars. 2001. Methodological individualism: Background, history and meaning. London, New York: Routledge.

Wernerfelt, Birger. 1984. “A Resource-based View of the Firm,” Strategic Management Journal 5: 171-180.

Wernerfelt, Birger. 1989. "From Critical Resources to Corporate Strategy," Journal of General Management 14: 4-12.

Williamson, Oliver E. 1996. “Economic Organization: The Case for Candor," Academy of Management Review, 21: 48-57.

Winter, Sidney G. 2003. “Understanding Dynamic Capabilities,” Strategic Management Journal 24: 991-995. 


\section{SMG - Working Papers \\ www.cbs.dk/smg \\ 2003}

2003-1: Nicolai J. Foss, Kenneth Husted, Snejina Michailova, and Torben Pedersen: Governing Knowledge Processes: Theoretical Foundations and Research Opportunities.

2003-2: Yves Doz, Nicolai J. Foss, Stefanie Lenway, Marjorie Lyles, Silvia Massini, Thomas P. Murtha and Torben Pedersen: Future Frontiers in International Management Research: Innovation, Knowledge Creation, and Change in Multinational Companies.

2003-3: Snejina Michailova and Kate Hutchings: The Impact of In-Groups and OutGroups on Knowledge Sharing in Russia and China CKG Working Paper.

2003-4: Nicolai J. Foss and Torben Pedersen : The MNC as a Knowledge Structure: The Roles of Knowledge Sources and Organizational Instruments in MNC Knowledge Management CKG Working Paper.

2003-5: Kirsten Foss, Nicolai J. Foss and Xosé H. Vázquez-Vicente: “Tying the Manager's Hands": How Firms Can Make Credible Commitments That Make Opportunistic Managerial Intervention Less Likely CKG Working Paper.

2003-6: Marjorie Lyles, Torben Pedersen and Bent Petersen: Knowledge Gaps: The Case of Knowledge about Foreign Entry.

2003-7: Kirsten Foss and Nicolai J. Foss: The Limits to Designed Orders: Authority under "Distributed Knowledge" CKG Working Paper.

2003-8: Jens Gammelgaard and Torben Pedersen: Internal versus External Knowledge Sourcing of Subsidiaries - An Organizational Trade-Off.

2003-9: Kate Hutchings and Snejina Michailova: Facilitating Knowledge Sharing in Russian and Chinese Subsidiaries: The Importance of Groups and Personal Networks Accepted for publication in Journal of Knowledge Management.

2003-10: Volker Mahnke, Torben Pedersen and Markus Verzin: The impact of knowledge management on MNC subsidiary performance: the role of absorptive capacity CKG Working Paper.

2003-11: Tomas Hellström and Kenneth Husted: Mapping Knowledge and Intellectual Capital in Academic Environments: A Focus Group Study Accepted for publication in Journal of Intellectual Capital CKG Working Paper.

2003-12: Nicolai J Foss: Cognition and Motivation in the Theory of the Firm: Interaction or "Never the Twain Shall Meet"? Accepted for publication in Journal des Economistes et des Etudes Humaines CKG Working Paper.

2003-13: Dana Minbaeva and Snejina Michailova: Knowledge transfer and expatriation practices in MNCs: The role of disseminative capacity.

2003-14: Christian Vintergaard and Kenneth Husted: Enhancing selective capacity through venture bases. 


\section{4}

2004-1: Nicolai J. Foss: Knowledge and Organization in the Theory of the Multinational Corporation: Some Foundational Issues

2004-2: Dana B. Minbaeva: HRM practices and MNC knowledge transfer

2004-3: Bo Bernhard Nielsen and Snejina Michailova: Toward a phase-model of global knowledge management systems in multinational corporations

2004-4: Kirsten Foss \& Nicolai J Foss: The Next Step in the Evolution of the RBV: Integration with Transaction Cost Economics

2004-5: Teppo Felin \& Nicolai J. Foss: Methodological Individualism and the Organizational Capabilities Approach

2004-6: Jens Gammelgaard, Kenneth Husted, Snejina Michailova: Knowledge-sharing Behavior and Post-acquisition Integration Failure

2004-7: Jens Gammelgaard: Multinational Exploration of Acquired R\&D Activities

2004-8: Christoph Dörrenbächer \& Jens Gammelgaard: Subsidiary Upgrading? Strategic Inertia in the Development of German-owned Subsidiaries in Hungary

2004-9: Kirsten Foss \& Nicolai J. Foss: Resources and Transaction Costs: How the Economics of Property Rights Furthers the Resource-based View

2004-10: Jens Gammelgaard \& Thomas Ritter: The Knowledge Retrieval Matrix: Codification and Personification as Separate Strategies

2004-11: Nicolai J. Foss \& Peter G. Klein: Entrepreneurship and the Economic Theory of the Firm: Any Gains from Trade?

2004-12: Akshey Gupta \& Snejina Michailova: Knowledge Sharing in Knowledge-Intensive Firms: Opportunities and Limitations of Knowledge Codification

2004-13: Snejina Michailova \& Kate Hutchings: Knowledge Sharing and National Culture: A Comparison Between China and Russia

\section{5}

2005-1: Keld Laursen \& Ammon Salter: My Precious - The Role of Appropriability Strategies in Shaping Innovative Performance

2005-2: Nicolai J. Foss \& Peter G. Klein: The Theory of the Firm and Its Critics: A Stocktaking and Assessment

2005-3: Lars Bo Jeppesen \& Lars Frederiksen: Why Firm-Established User Communities Work for Innovation: The Personal Attributes of Innovative Users in the Case of Computer-Controlled Music

2005-4: Dana B. Minbaeva: Negative Impact of Hrm Complementarity on Knowledge Transfer in Mncs

2005-5: Kirsten Foss, Nicolai J. Foss, Peter G. Klein \& Sandra K. Klein: Austrian Capital Theory and the Link Between Entrepreneurship and the Theory of the Firm 
2005-1: Nicolai J. Foss: The Knowledge Governance Approach

2005-2: Torben J. Andersen: Capital Structure, Environmental Dynamism, Innovation Strategy, and Strategic Risk Management

2005-3: Torben J. Andersen: A Strategic Risk Management Framework for Multinational Enterprise

2005-4: Peter Holdt Christensen: Facilitating Knowledge Sharing: A Conceptual Framework

2005-5 Kirsten Foss \& Nicolai J. Foss: Hands Off! How Organizational Design Can Make Delegation Credible

2005-6 Marjorie A. Lyles, Torben Pedersen \& Bent Petersen: Closing the Knowledge Gap in Foreign Markets - A Learning Perspective

2005-7 Christian Geisler Asmussen, Torben Pedersen \& Bent Petersen: How do we capture "Global Specialization" when measuring firms' degree of internationalization?

2005-8 Kirsten Foss \& Nicolai J. Foss: Simon on Problem-Solving: Implications for New Organizational Forms

2005-9 Birgitte Grøgaard, Carmine Gioia \& Gabriel R.G. Benito: An Empirical Investigation of the Role of Industry Factors in the Internationalization Patterns of Firms

2005-10 Torben J. Andersen: The Performance and Risk Management Implications of Multinationality: An Industry Perspective

2005-11 Nicolai J. Foss: Scientific Progress in Strategic Management: The case of the Resource-based view 